\title{
Simple water balance model and crop water demand at different spatial and temporal scales in Periya Pallam catchment of upper Bhavani basin, Tamilnadu
}

\author{
A. Raviraj 网 \\ Department of Irrigation and Drainage Engineering, Agricultural Engineering College and Research Institute, Tamil Nadu Agricultural \\ University (TNAU), Kumulur, Trichy, Tamilnadu, India
}

J. Ramachandran

Department of Agricultural Engineering, Agricultural College and Research Institute, TNAU, Madurai, Tamilnadu, India

Nitin Kaushal

River Basin Management, World Wide Fund for Nature - India

Arjit Mishra

World Wide Fund for Nature - India

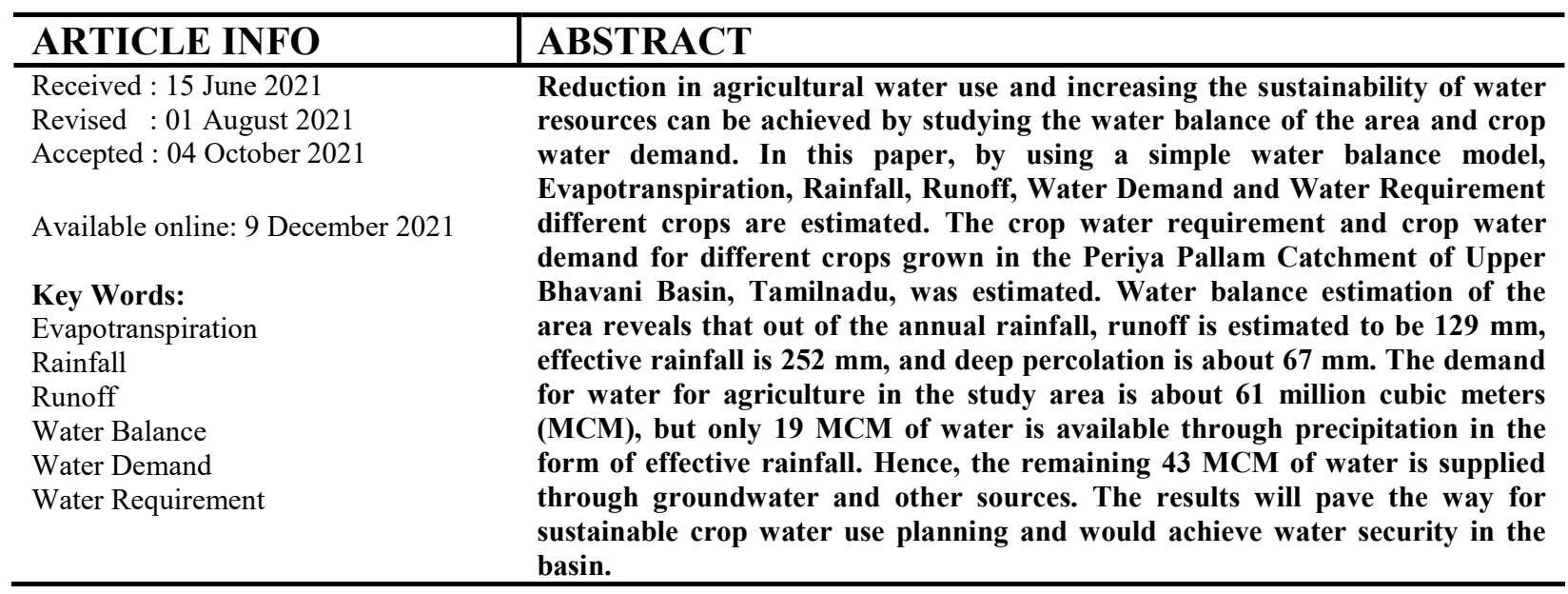

\section{Introduction}

Water scarcity is a principal constraint in crop production (Bhutiani and Ahamad, 2019). Agricultural activity governs the use of freshwater and $70 \%$ of withdrawals from water resources globally (FAO, 2002). Scarcity of water leads to drought which have a severe effect on people and also on agricultural activity (Pereira et al., 2007). The need of the hour is sustainable use of agricultural water which can be done by studying the water balance of the area and crop water demand. Studying water balance is a necessary prerequisite to improve crop-water usage and reduce losses due to evaporation and surface runoff. Hydrology scientists are interested in simulating hydrological behavior over a large domain. Thornthwaite (1948) and Thornthwaite and Mather
(1957) first developed water balance models in the 1940s and 1950s. The water balance analysis tells how much amount of precipitation, evapotranspiration, groundwater recharge, and soil storage percentage is for the understanding of the hydrological cycle (Lijuan et al., 2008). Chabi et al. (2019) expressed that understanding water balance will help in minimizing the short, medium, and long term water shortages which is due to climate change. It will help in managing or mitigating face the water requirements of local use. Crop water requirement refers to the quantity of water required to recompense for the evapotranspiration from field crop (Allen et al., 1998). A precise estimate of crop evapotranspiration aids in the effective management of water resources (Cai et al., 2007;

Corresponding author E-mail: rraj@tnau.ac.in

Doi: https://doi.org/10.36953/ECJ.2021.22326

This work is licensed under Attribution-Non Commercial 4.0 International (CC BY-NC 4.0)

(C) ASEA 
Lovelli et al., 2008). Crop water demand is the product of crop water requirement and planting area. Several studies in evaluating crop water demand have been conducted globally, including in India (Pandey et al., 2008; Rao and Poonia 2011). The information on irrigation strategies for local crop production was extracted as a result of these studies.

This study is taken up in the Periya Pallam Catchment of Upper Bhavani Basin with the following objectives. (i) To study the various components of the water balance estimation for delineated Upper Bhavani Basin (ii) To the cropwater requirement of major crops in the basin and estimate the time series water demand for the basin. The present study focuses on the water demand for agriculture in the future, changes in the cropping pattern, and measures to reduce the supply-demand gap to achieve sustainability. The results derived from the study will pave the way for sustainable crop water use planning and would achieve water security in the basin.

\section{Material and Methods Study Area}

The Bhavani basin is the sub-basin in the Cauvery basin spread over in Karnataka, Kerala, and Tamil $\mathrm{Nadu}$, with the majority of the catchment laying in Tamil Nadu. The main river courses through Coimbatore, Nilgiris, and Erode districts of Tamil Nadu. About $90 \%$ of the river's water is used for irrigation. The study area is limited to the upper Bhavani basin, which includes Periya Pallam Catchment of Coimbatore district. Figure1 shows the exact location of the study area in the Bhavani basin. There are three sub-catchment in the Periya Pallam Catchment area, and the boundaries of the sub-catchment are shown in figure 2. The major crops grown in the priority area include Sugarcane, Banana, vegetables, etc.

\section{Simple Water Balance Model}

The most commonly used crop-water balance model is given by equation 1 as follow as:

$$
\mathrm{ET}=\mathrm{P}+\mathrm{I}-\mathrm{S}-\mathrm{D}-\mathrm{R}
$$

where ET is evapotranspiration, $\mathrm{P}$ is precipitation, I is irrigation, $\mathrm{S}$ is change in soil water storage, $\mathrm{D}$ is deep drainage, and $\mathrm{R}$ is runoff.

\section{Estimation of Water Balance Components}

Water balance is an important technique to bring out the relationship between precipitation and potential evapotranspiration and plays a significant role in water resources and agriculture development in a basin.

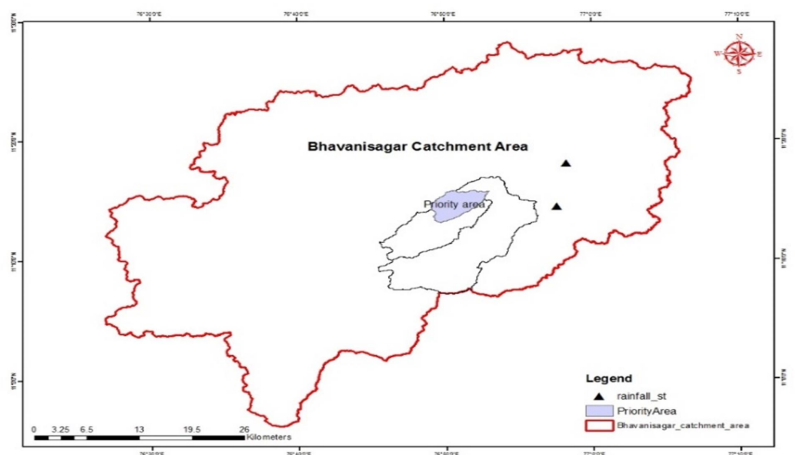

Figure 1: Location of Rain gauge stations in the study area

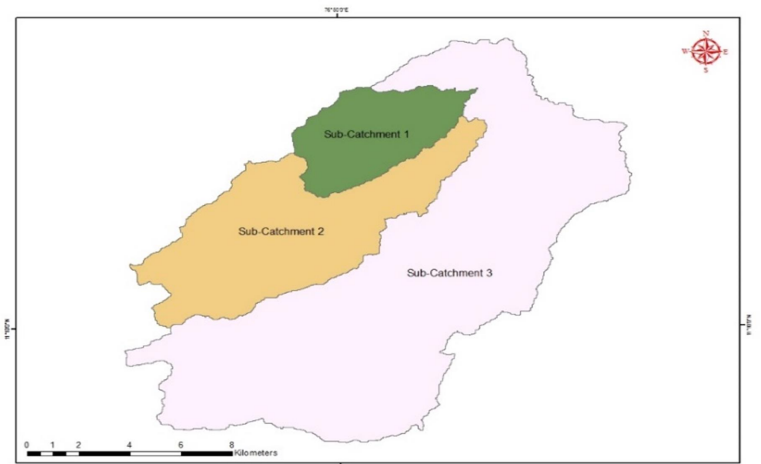

Figure 2: Sub-Catchment in the Periya Pallam Catchment

\section{Rainfall}

Precipitation is input to the hydrologic cycle, which is estimated in all water budget calculations. The available rainfall recording stations nearby the priority area is Mettupalayam and Tholampalayam (figure1). Since the Tholampalayam station is more close to the priority area, Tholampalayam station data is used for the study. The temporal changes in rainfall were studied over a period of 11 years (2007-2017).

\section{Runoff}

Surface runoff is calculated by the curve number method (CN), developed by the Soil Conservation Service (SCS) in 1954. The curve number for each land use/land cover class is given. The hydrologic soil group of each land use depends upon the soil texture. Based on the soil texture in the study area, the hydrologic soil group is assigned. The weighted curve number for the entire area is calculated based on equation 2 as follow as: 


$$
\text { Weighted } C N=\frac{\sum C N^{*} A}{A_{\text {total }}}
$$

Where $T_{\max }$ and $T_{\min }$ are maximum and minimum temperature; $\mathrm{T}_{\text {mean }}$ is the mean temperature; $\mathrm{R}_{\mathrm{a}}$ is the extraterrestrial radiation. The maximum and Where $\mathrm{CN}$ is the curve number of each land use, and $\mathrm{A}$ is the area of each land use, and $\mathrm{A}_{\text {total }}$ is a total area. Based on the weighted $\mathrm{CN}$ and rainfall, the potential maximum retention $(\mathrm{S})$ is calculated using equation 3 :

$$
C N=\frac{25400}{254+S}
$$

Then the depth of runoff $(\mathrm{Q})$ is calculated using the SCS-CN method (equation 4):

$$
Q=\frac{(P-0.3 S)^{2}}{P+0.7 S}
$$

\section{Effective Rainfall}

The quantity of rainfall effectively be used by plants is effective rainfall in agricultural production. Runoff (Q) and Deep Percolation (DP) are the ways of water loss that make the entire rainwater unavailable for plants. Infiltration of rainwater is based on soil type, slope, crop canopy, storm intensity, and the initial soil moisture. Effective rainfall is calculated using equation 5 and 6.

$$
\begin{gathered}
\mathrm{P}_{\text {eff }}=\left(0.6 * \mathrm{P}_{\text {month }}\right)-10 \text { for } \mathrm{P}_{\text {month }}<=70 \mathrm{~mm} \text {---------- } 5 \\
\mathrm{P}_{\text {eff }}=\left(0.7 * \mathrm{P}_{\text {month }}\right)-24 \text { for } \mathrm{P}_{\text {month }}>70 \mathrm{~mm}--------6
\end{gathered}
$$

\section{Infiltration and Deep Percolation}

The vertical entry of water into the soil is called infiltration, and the amount of water percolating and recharging the groundwater is called deep percolation. The difference between rainfall and effective rainfall is the sum of runoff, infiltration, and deep percolation. Excluding the runoff and infiltration, a deep percolation component is obtained. It is assumed that $30 \%$ of water entering into the soil deep percolates. Thus, the infiltration and deep percolation are calculated.

\section{Evapotranspiration}

The reference crop $\left(\mathrm{ET}_{\mathrm{o}}\right)$ represents the water use of a standard crop in that environment. In this study, the Hargreaves equation is used for the estimation of $\mathrm{ET}_{\mathrm{o}}$. When solar radiation data, relative humidity data, and/or wind speed data are missing, instead of estimating those data, $\mathrm{ET}_{\mathrm{o}}$ can be estimated using the Hargreaves $\mathrm{ET}_{\mathrm{o}}$ equation 7.

$$
E T_{0}=0.0023\left(T_{\text {mean }}+17.8\right)\left(T_{\max }-T_{\text {min }}\right)^{0.5} R_{a}
$$

minimum temperature is used, and the average temperature over 2006 to 2016 is used to find the evapotranspiration.

\section{Crop Evapotranspiration}

The crop evapotranspiration is estimates as the product of reference evapotranspiration and crop coefficient. It is given by equation 8 :

$$
E T_{c}=E T_{0} * K_{c}
$$

Where: $\mathrm{ET}_{\mathrm{c}}=$ actual crop evapotranspiration rate; $\mathrm{K}_{\mathrm{c}}=$ crop coefficient; $\mathrm{ET}_{\mathrm{o}}=$ evapotranspiration calculated using the Hargreaves' Method. The crop coefficients for major crops grown in the study area at different stages are taken from Allen et al. (1998), and the crop evapotranspiration is estimated.

\section{Time series water demand for the study area}

Water Demand (Agriculture) includes water requirements for the crop along with field preparation and other activities. The crop evapotranspiration is multiplied by the area grown given the total volume of water required or evaporative demand. The crop-grown areas for Banana, Paddy, Millets, Green gram, Groundnut, Gingelly (Sesame), Sunflower, and Sugarcane are taken from the Handbook of Karamadai block. The effective rainfall throughout the growing period for different crops is multiplied with crop grown area to estimate the total volume of the water available for the crop. The difference between the evaporative demand and effective rainfall gives the demand for the priority area.

\section{Results and Discussion Water Balance Components}

The analysis of rainfall data showed that average annual rainfall recorded at Tholampalayam station was $604 \mathrm{~mm}$. The temporal changes in rainfall over a period of 11 years (2007-2017) revealed that out of the eleven years of observation, five years recorded more than the normal rainfall and the remaining six years recorded less than the normal rainfall (figure 3). It was also found that maximum rainfall was recorded in the year 2011 and the lowest rainfall was recorded in the year 2016. The priority area receives about $7 \%$ of its rainfall in 
Winter (January and February); 27\% rainfall in Summer (March to May); $16 \%$ of its rainfall in Southwest Monsoon (June to September), and the majority of the contribution is from Northeast monsoon (October to December) accounting for $50 \%$ (figure 4). The considerable rainfall from northeast monsoon during October to December, has great significance in agriculture and allied sectors in these regions. Proper understanding of the seasonal prediction of northeast monsoon rainfall have considerable application value for decision making in agriculture and water resource sectors of these regions (Samui et al., 2013). Lijuan et al. (2008) indicated that the water balance analysis is useful for understanding the hydrological processes in the Xitiaoxi catchment.

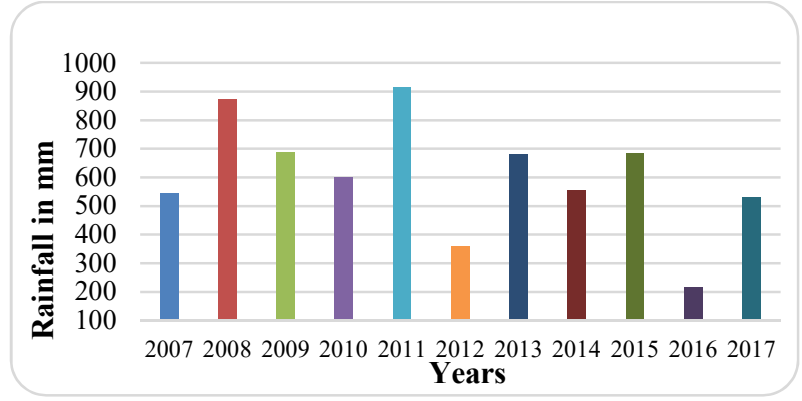

Figure 3: Annual rainfall variation in the priority area

\section{Season Rainfall Variation}

Winter $\square$ Summer $\square$ SWM NEM

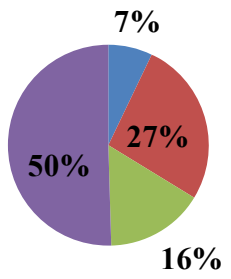

Figure 4: Seasonal rainfall variation in the priority area

\section{Runoff}

Surface runoff is computed using the runoff $\mathrm{CN}$ method, in which the weighted curve number for the Upper Bhavani Basin (UBB) is about 68. The potential maximum retention is about $119 \mathrm{~mm}$. The low value of weighted $\mathrm{CN}$ indicates the availability of good forest cover. The quantity of runoff generated from the UBB on a monthly basis is presented in Table 1. Similarly, the curve number for three sub-catchments and the entire Periya Pallam catchment is calculated as $71,75,72$, and 72 , respectively. The greater curve numbers represent a greater proportion of surface runoff (Stuebe and Johnston, 1990; Schulze et al., 1992). Since the CN number of Periya Pallam catchment and Sub-Catchment 3 are the same, the runoff in depth units is the same (Table 2). It differs by the volume of runoff generated. Around $27 \mathrm{Mm}^{3}$ of water is generated as runoff from the Periya Pallam catchment and $17 \mathrm{Mm}^{3}$ of runoff from SubCatchment 3. The quantity of runoff generated from the three sub-catchments and the entire Periya Pallam catchment on a monthly basis is presented in Table 2 - 5. Providing an accurate runoff generation within a basin is an important factor in developing a strategic runoff harvesting plan to overcome water scarce problem (Saravanan et al., 2015).

The quantity of effective rainfall that can effectively be used by plants is calculated by USDA Method, and it is presented in Table 1-5. It was found that from average annual rainfall of 604 $\mathrm{mm}, 250 \mathrm{~mm}$ of rainfall is available for the plants in the form of effective rainfall. The residual quantity of effective rainfall and runoff from rainfall infiltrates into the soil. From the entire UBB, 172 and $73 \mathrm{~mm}$ of total rainfall infiltrates into the soil (Table 1). Around one-third of the total rainfall infiltrates in UBB. In the Periya Pallam catchment, the total rainwater that infiltrates into the soil is around $158 \mathrm{~mm}$. The deep percolation component estimated from this study is around 67 $\mathrm{mm}$. The good clay content in the soils of the priority area is the causing factor for this lesser deep percolation ( $10 \%$ of total rainfall). It also has a greater advantage that the water harvesting potential in the priority area and also effective replenishment of soil water in the effective plant root zone (Table 2). The average monthly evapotranspiration for the study area is shown in figure 5. The evapotranspiration is maximum during the month of March, April, and May, which is around $6 \mathrm{~mm} /$ day. The estimation of evapotranspiration is of great importance for agricultural, hydrological and climatic studies, as it constitutes a major part of the hydrological cycle (Sobrino et al., 2005). 
Table 1: Monthly water balance estimation for the Upper Bhavani Basin

\begin{tabular}{|l|c|c|c|c|c|c|c|c|c|c|c|c|c|}
\hline Month & Jan & Feb & Mar & Apr & May & Jun & Jul & Aug & Sep & Oct & Nov & Dec & Total \\
\hline Rainfall (mm) & 3.2 & 39.7 & 45.0 & 48.8 & 66.9 & 18.2 & 14.2 & 28.4 & 35.0 & 159.1 & 106.7 & 38.8 & 603.9 \\
\hline Runoff (mm) & 0.0 & 0.1 & 0.6 & 1.3 & 6.4 & 3.1 & 4.8 & 0.5 & 0.0 & 62.5 & 26.4 & 0.1 & 105.8 \\
\hline $\begin{array}{l}\text { Eff Rainfall } \\
\text { (mm) }\end{array}$ & 0.0 & 13.8 & 17.0 & 19.3 & 30.2 & 0.9 & 0.0 & 7.0 & 11.0 & 85.4 & 54.0 & 13.3 & 251.9 \\
\hline ET $_{\mathbf{0}}(\mathbf{m m})$ & 4.6 & 5.4 & 6.1 & 6.4 & 6.2 & 5.3 & 4.8 & 5.1 & 5.2 & 4.8 & 4.2 & 4.1 & 62.2 \\
\hline Infiltration (mm) & 2.2 & 18.0 & 19.1 & 19.8 & 21.3 & 9.9 & 6.6 & 14.6 & 16.8 & 7.8 & 18.4 & 17.8 & 172.3 \\
\hline DP (mm) & 1.0 & 7.7 & 8.2 & 8.5 & 9.1 & 4.3 & 2.8 & 6.3 & 7.2 & 3.3 & 7.9 & 7.6 & 73.9 \\
\hline
\end{tabular}

Table 2: Monthly water balance estimation for the Periya Pallam catchment

\begin{tabular}{|l|c|c|c|c|c|c|c|c|c|c|c|c|c|}
\hline Month & Jan & Feb & Mar & Apr & May & Jun & Jul & Aug & Sep & Oct & Nov & Dec & Total \\
\hline Rainfall (mm) & 3.2 & 39.7 & 45.0 & 48.8 & 66.9 & 18.2 & 14.2 & 28.4 & 35.0 & 159.1 & 106.7 & 38.8 & 603.9 \\
\hline Runoff (mm) & 0.0 & 0.9 & 2.1 & 3.1 & 10.2 & 1.5 & 2.9 & 0.0 & 0.3 & 73.4 & 33.8 & 0.8 & 129.0 \\
\hline Eff Rainfall (mm) & 0.0 & 13.8 & 17.0 & 19.3 & 30.2 & 0.9 & 0.0 & 7.0 & 11.0 & 85.4 & 54.0 & 13.3 & 251.9 \\
\hline ET $_{\mathbf{0}}(\mathbf{m m})$ & 4.6 & 5.4 & 6.1 & 6.4 & 6.2 & 5.3 & 4.8 & 5.1 & 5.2 & 4.8 & 4.2 & 4.1 & 62.2 \\
\hline Infiltration (mm) & 2.2 & 17.5 & 18.1 & 18.5 & 18.6 & 11.0 & 7.9 & 14.9 & 16.6 & 0.1 & 13.2 & 17.3 & 156.1 \\
\hline DP (mm) & 1.0 & 7.5 & 7.8 & 7.9 & 8.0 & 4.7 & 3.4 & 6.4 & 7.1 & 0.1 & 5.7 & 7.4 & 66.9 \\
\hline
\end{tabular}

Note: Rainfall above $5 \mathrm{~mm}$ is expected to generate runoff as per the SCS-CN method

Table 3: Monthly water balance estimation for the Sub-Catchment 1.

\begin{tabular}{|l|c|c|c|c|c|c|c|c|c|c|c|c|c|}
\hline Month & Jan & Feb & Mar & Apr & May & Jun & Jul & Aug & Sep & Oct & Nov & Dec & Total \\
\hline Rainfall (mm) & 3.2 & 39.7 & 45.0 & 48.8 & 66.9 & 18.2 & 14.2 & 28.4 & 35.0 & 159.1 & 106.7 & 38.8 & 603.9 \\
\hline Runoff (mm) & 0.0 & 0.7 & 1.6 & 2.6 & 9.2 & 1.8 & 3.3 & 0.1 & 0.1 & 70.7 & 31.9 & 0.5 & 122.5 \\
\hline Eff Rainfall (mm) & 0.0 & 13.8 & 17.0 & 19.3 & 30.2 & 0.9 & 0.0 & 7.0 & 11.0 & 85.4 & 54.0 & 13.3 & 251.9 \\
\hline ET $_{\mathbf{0}}(\mathbf{m m})$ & 4.6 & 5.4 & 6.1 & 6.4 & 6.2 & 5.3 & 4.8 & 5.1 & 5.2 & 4.8 & 4.2 & 4.1 & 62.2 \\
\hline Infiltration (mm) & 2.2 & 17.7 & 18.4 & 18.9 & 19.3 & 10.8 & 7.6 & 14.9 & 16.7 & 2.1 & 14.6 & 17.5 & 160.7 \\
\hline DP (mm) & 1.0 & 7.6 & 7.9 & 8.1 & 8.3 & 4.6 & 3.3 & 6.4 & 7.2 & 0.9 & 6.2 & 7.5 & 68.9 \\
\hline
\end{tabular}

Table 4: Monthly water balance estimation for the Sub-Catchment 2

\begin{tabular}{|l|c|c|c|c|c|c|c|c|c|c|c|c|c|}
\hline Month & Jan & Feb & Mar & Apr & May & Jun & Jul & Aug & Sep & Oct & Nov & Dec & Total \\
\hline Rainfall (mm) & 3.2 & 39.7 & 45.0 & 48.8 & 66.9 & 18.2 & 14.2 & 28.4 & 35.0 & 159.1 & 106.7 & 38.8 & 603.9 \\
\hline Runoff (mm) & 0.0 & 2.1 & 3.7 & 5.1 & 13.7 & 0.7 & 1.7 & 0.1 & 1.0 & 81.8 & 39.8 & 1.8 & 151.4 \\
\hline Eff Rainfall (mm) & 0.0 & 13.8 & 17.0 & 19.3 & 30.2 & 0.9 & 0.0 & 7.0 & 11.0 & 85.4 & 54.0 & 13.3 & 251.9 \\
\hline ET $_{\mathbf{0}}(\mathbf{m m})$ & 4.6 & 5.4 & 6.1 & 6.4 & 6.2 & 5.3 & 4.8 & 5.1 & 5.2 & 4.8 & 4.2 & 4.1 & 62.2 \\
\hline Infiltration (mm) & 2.2 & 16.7 & 17.0 & 17.1 & 16.2 & 11.6 & 8.7 & 14.9 & 16.1 & 0.0 & 9.0 & 16.6 & 146.1 \\
\hline DP (mm) & 1.0 & 7.1 & 7.3 & 7.3 & 6.9 & 5.0 & 3.7 & 6.4 & 6.9 & 0.0 & 3.9 & 7.1 & 62.6 \\
\hline
\end{tabular}

Table 5: Monthly water balance estimation for the Sub-Catchment 3

\begin{tabular}{|l|c|c|c|c|c|c|c|c|c|c|c|c|c|}
\hline Month & Jan & Feb & Mar & Apr & May & Jun & Jul & Aug & Sep & Oct & Nov & Dec & Total \\
\hline Rainfall (mm) & 3.2 & 39.7 & 45.0 & 48.8 & 66.9 & 18.2 & 14.2 & 28.4 & 35.0 & 159.1 & 106.7 & 38.8 & 603.9 \\
\hline Runoff (mm) & 0.0 & 0.9 & 2.1 & 3.1 & 10.2 & 1.5 & 2.9 & 0.0 & 0.3 & 73.4 & 33.8 & 0.8 & 129.0 \\
\hline Eff Rainfall (mm) & 0.0 & 13.8 & 17.0 & 19.3 & 30.2 & 0.9 & 0.0 & 7.0 & 11.0 & 85.4 & 54.0 & 13.3 & 251.9 \\
\hline ET $_{\mathbf{0}}(\mathbf{m m})$ & 4.6 & 5.4 & 6.1 & 6.4 & 6.2 & 5.3 & 4.8 & 5.1 & 5.2 & 4.8 & 4.2 & 4.1 & 62.2 \\
\hline Infiltration (mm) & 2.2 & 17.5 & 18.1 & 18.5 & 18.6 & 11.0 & 7.9 & 14.9 & 16.6 & 0.1 & 13.2 & 17.3 & 156.1 \\
\hline DP (mm) & 1.0 & 7.5 & 7.8 & 7.9 & 8.0 & 4.7 & 3.4 & 6.4 & 7.1 & 0.1 & 5.7 & 7.4 & 66.9 \\
\hline
\end{tabular}


Table 6: Crop water requirement of different crops grown in the study area

\begin{tabular}{|l|c|c|c|c|c|c|c|c|c|c|c|}
\hline SN & Crop & Plant & Ini & Dev & Mid & Late & \multicolumn{1}{c}{ Total } & \multicolumn{3}{|c|}{ Kc } & ET $_{\mathbf{c}}$ Calculated \\
\cline { 8 - 12 } & & & & & & Days & Ini & Mid & Late & (mm) \\
\hline 1 & Green gram & March & 20 & 30 & 30 & 20 & 100 & 0.40 & 1.05 & 0.47 & $\mathbf{2 5 8}$ \\
\hline 2 & Sunflower & May & 25 & 35 & 45 & 25 & 130 & 0.35 & 1.07 & 0.35 & $\mathbf{4 0 5}$ \\
\hline 3 & Millets & April & 20 & 30 & 55 & 35 & 140 & 0.30 & 1.00 & 0.30 & $\mathbf{4 4 3}$ \\
\hline 4 & Groundnut & May & 35 & 35 & 35 & 35 & 140 & 0.40 & 1.15 & 0.60 & $\mathbf{4 6 2}$ \\
\hline 5 & Paddy & Dec & 30 & 30 & 30 & 30 & 120 & 1.05 & 1.20 & 0.75 & $\mathbf{5 4 5}$ \\
\hline 6 & $\begin{array}{c}\text { Gingelly } \\
\text { (Sesame) }\end{array}$ & June & 20 & 30 & 40 & 20 & 110 & 0.35 & 1.10 & 0.25 & $\mathbf{5 6 6}$ \\
\hline 7 & Paddy & Dec & 30 & 45 & 45 & 30 & 150 & 1.05 & 1.20 & 0.75 & $\mathbf{7 5 4}$ \\
\hline 8 & Banana & March & 120 & 90 & 120 & 60 & 390 & 0.50 & 1.10 & 1.00 & $\mathbf{1 7 7 9}$ \\
\hline 9 & Sugarcane & Jan & 35 & 60 & 190 & 120 & 405 & 0.40 & 1.25 & 0.75 & $\mathbf{1 9 0 1}$ \\
\hline
\end{tabular}

Table 7: Demand of water requirement for different crops in Karamadai block

\begin{tabular}{|c|c|c|c|c|c|c|c|c|c|c|}
\hline \multirow[t]{2}{*}{ Crop } & \multirow{2}{*}{$\begin{array}{l}\mathbf{E T}_{\mathbf{c}} \\
\mathbf{m m} \\
\end{array}$} & \multicolumn{2}{|c|}{ Total Area } & \multicolumn{2}{|c|}{$\begin{array}{l}\text { Volume of Water } \\
\text { Required }\left(\mathrm{Mm}^{3}\right)\end{array}$} & \multirow{2}{*}{$\begin{array}{c}\begin{array}{c}\text { Effective } \\
\text { Rainfall }\end{array} \\
\text { mm }\end{array}$} & \multicolumn{2}{|c|}{$\begin{array}{l}\text { Volume of Water } \\
\text { Available }\left(\mathrm{Mm}^{3}\right)\end{array}$} & \multicolumn{2}{|c|}{$\begin{array}{c}\text { Supply- } \\
\text { Demand Gap } \\
\left(\mathrm{Mm}^{3}\right)\end{array}$} \\
\hline & & 2006 & 2016 & 2006 & 2016 & & 2006 & 2016 & 2006 & 2016 \\
\hline Paddy & 545 & 60.32 & 0.38 & 0.33 & 0.00 & 44.00 & 0.03 & 0.00 & 0.30 & 0.00 \\
\hline Millets & 443 & 99.81 & 429.32 & 0.44 & 1.90 & 54.00 & 0.05 & 0.23 & 0.39 & 1.67 \\
\hline $\begin{array}{l}\text { Green } \\
\text { gram }\end{array}$ & 258 & 103.83 & 139.79 & 0.27 & 0.36 & 67.00 & 0.07 & 0.09 & 0.20 & 0.27 \\
\hline Groundnut & 462 & 250.21 & 118.15 & 1.16 & 0.55 & 49.00 & 0.12 & 0.06 & 1.03 & 0.49 \\
\hline $\begin{array}{l}\text { Gingelly } \\
\text { (Sesame) }\end{array}$ & 566 & 20.94 & 51.15 & 0.12 & 0.29 & 19.00 & 0.00 & 0.01 & 0.11 & 0.28 \\
\hline Sunflower & 405 & 19.17 & 1.00 & 0.08 & 0.00 & 49.00 & 0.01 & 0.00 & 0.07 & 0.00 \\
\hline Sugarcane & 1901 & 287.17 & 85.66 & 5.46 & 1.63 & 264.00 & 0.76 & 0.23 & 4.70 & 1.40 \\
\hline
\end{tabular}

The components of the water balance were estimated. It was found that total annual rainfall is around $604 \mathrm{~mm}$; effective rainfall is around 252 $\mathrm{mm}$, and evapotranspiration is around $72 \mathrm{~mm}$. In Periya Pallam, the total available water for the cropping in the form of precipitation is around 52 $\mathrm{Mm}^{3}$. If the entire runoff is effectively harvested, around $27 \mathrm{Mm}^{3}$ of water can be harvested and used for agriculture and allied activities. Further, about $14 \mathrm{Mm}^{3}$ of water is recharging the groundwater. With the understanding of available water in a basin, irrigation scheduling, crop rotation, and cropping pattern can be planned.

\section{Crop evapotranspiration}

The total water required throughout the growing period is crop evapotranspiration. The crop evapotranspiration for different crops like Banana, Paddy, Millets, Green gram, Gingelly, Sunflower, Sugarcane, and Groundnuts are calculated and presented in Table 6 . The green gram was found to be the low water requirement crop, and banana and sugarcane are high water requirement and annual crops. The water demand for various crops in the Karamadai blocks viz., Paddy, Millets, Green gram, Groundnut, Gingelly (Sesame), Sunflower and Sugarcane are given in Table 7. The results reveal that the total volume of water that is required for meeting the above-mentioned crop water requirement is about $61 \mathrm{Mm}^{3}$. But only $19 \mathrm{Mm}^{3}$ of water is supplied through precipitation in the form of effective rainfall. The remaining $43 \mathrm{Mm}^{3}$ of water should be given through other water resources. There is a great increase in cropping area of Millets, Green gram, Gingelly at the same time, the demand of water requirement is also less compared to other crops. The crop water requirement can be used for the determination of crop pattern suitable for the locality. It can pave way for the improved productivity and hence better national wealth. The following strategies can be adopted to overcome the water-scarce situation and to improve the water use efficiency in the priority 


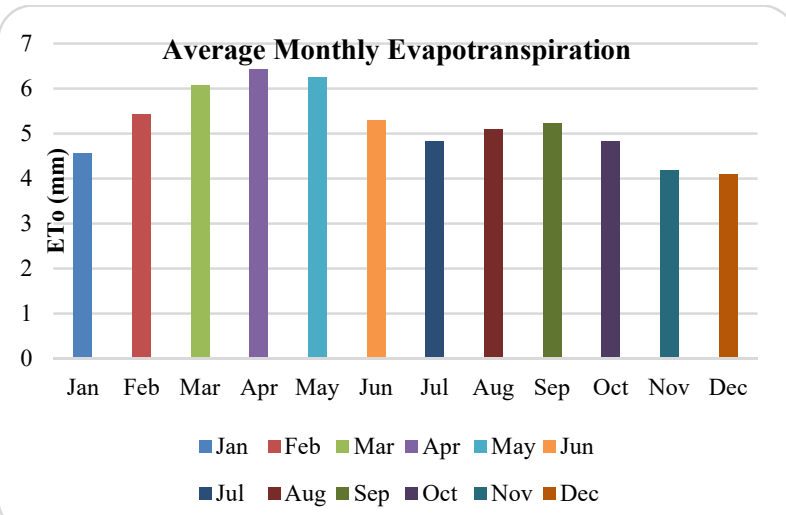

Figure 5: Average monthly evapotranspiration in the priority area

area: (i) opt for alternate cropping pattern instead of going for high water-consuming crops, (ii) Implementation of integrated watershed management programs including in-situ soil and moisture conservation programmes to augment the rainwater and to improve the groundwater situation, (iii) Afforestation programmes to increase the percentage of tree cover, (iv) Implementation of micro-irrigation technology for water-saving and yield increase, (v) Large scale adoption of farm ponds to harvest the runoff potential in the priority area.

\section{Conclusion}

Water scarcity is becoming a key issue in most of the river basins in India with the majority of the water use is taken up by the agriculture sector of about $80 \%$ followed by industrial and domestic sector, it is imperative that in future the contribution of water to agriculture would be reduced and it is shared among the domestic and industrial sectors. Hence, water management plays a key role in the agriculture sector to increase

\section{References}

Allen, R. G., Pereira, L. S., Raes, D., \& Smith, M. (1998). Crop Evapotranspiration: Guidelines for Computing Crop Water Requirements, FAO Irrigation and Drainage Paper 56. U.N. Food and Agriculture Organization (FAO), Rome. 7-9.

Bhutiani, R., \& Ahamad, F. (2019). A case study on changing pattern of agriculture and related factors at Najibabad region of Bijnor, India. Contaminants in Agriculture and Environment: Health Risks and Remediation, 1, 236. productivity and water use efficiency with reduced water availability. The normal rainfall of the priority area is around $604 \mathrm{~mm}$, with the majority of occurrence is in the Northeast monsoon (50\%), followed by summer (27\%), southwest monsoon $(16 \%)$, and winter $(7 \%)$. Water balance estimation of the area reveals that out of the annual rainfall, runoff is estimated to be $129 \mathrm{~mm}$, effective rainfall is $252 \mathrm{~mm}$, and deep percolation is about $67 \mathrm{~mm}$. Runoff is maximum during the months of October and November, wherein the potential of rainwater harvesting is more in the area. The minimum amount of deep percolation of $10 \%$ is limiting the groundwater recharge in the study area leading to declining groundwater tables over the years. Further, it was also understood that about $27 \mathrm{MCM}$ of water could be harvested and supplemented for agriculture and allied activities, and about $14 \mathrm{MCM}$ of water can be recharged underground. The demand for water for agriculture in the study area is about $61 \mathrm{MCM}$, but only $19 \mathrm{MCM}$ of water is available through precipitation in the form of effective rainfall. Therefore, the remaining 43 MCM of water is supplied through groundwater and other sources. Hence, it is highly recommended to go for micro-irrigation to avoid over-exploitation of groundwater in the priority area. And the groundwater depleted zones has to be identified and measures has to be taken to improve the ground water situation through artificial recharge of depleted groundwater aquifers. The water balance model used in this study focus more on the surface component and hence for further water budget modelling consideration of two main components, namely surface water and groundwater resources will enhance the assessments and adequately portray crop water demand.

Cai, J. B., Liu, Y., Lei, T. W., \& Pereira, L. S. (2007). Estimating reference evapotranspiration with the FAO Penman-Monteith equation using daily weather forecast messages. Agricultural and Forest Meteorology. 145: 2235 .

Chabi, A., Alamou, E. A., Biao, E. I., Obada, E., \& Zandagba, J. (2019) Assessment of Water Balance in the Ilauko Reservoir of the Ouémé at Savè Catchment (Benin, West Africa), Hydrology. 7(1): 15-23. doi: 10.11648/j.hyd.20190701.13 
FAO. (2002) Crops and drops: making the best use of water for agriculture. FAO, Rome, Italy. 28.

Gupta S. K. \& Deshpande, R. D., (2004). Water for India in 2050: First-order assessment of available options. Current Science. 86(9). 1216-1224.

Lijuan, X., Lijiao, L., \& Qi, Z., (2008). Hydrological behavior and water balance analysis for Xitiaoxi catchment of Taihu Basin. Water Science and Engineering. 1(3): 44-53.

Lovelli, S., Perniola, M., Arcieri, M., Rivelli, A. R., \& Tommason, T. D. (2008). Water use assessment in muskmelon by the Penman-Monteith "one-step" approach. Agricultural Water Management. 95: 1153-1160.

Pandey, V., Patel, V. J., Vadodaria, R. P., Patel, H. R., \& Shekh, A. M. (2008). Irrigation water requirement and production potentials of major crops over Narmada canal command area in Gujarat. Journal of Agrometeorology. 10: 314-320.

Pereira, J. S., Chaves, M. M., Caldeira, M. C., \& Correia, A. V. (2007). Plant growth \& climate change. Oxford, UK Blackwell Publishing, 118-145.

Rao, A. S., \& Poonia, S. (2011). Climate change impact on crop water requirements in arid Rajasthan. Journal of Agrometeorology, 13: 17-24.

Samui, R., Kamble, M., \& Sabale, J. (2013). Northeast monsoon rainfall and agricultural production in Tamilnadu and Andhra Pradesh I - Rainfall variability and its significance in agricultural production. Mausam. 64. 309316.

Saravanan, K., Mohan, K., Kasiviswanathan, K.S., \& Saravanan, S., (2015). A GIS-Based Approach for Identifying Potential Runoff Harvesting Sites in the Bhavani Watershed, Tamilnadu, India. Aust. J. Basic \& Appl. Sci., 9(27): 479-486.

Schulze, R.E., Scmidt, E.J. \& Smithers, J.C. (1992). PC-based SCS design flood estimates for small catchments in Southern Africa. Department of Agricultural Engineering, University of Natal.

Sobrino, J.A., Gomez, M., Jimenez-Munoz, J.C., Olioso, A., \& Chehbouni, G. (2005). A simple algorithm to estimate evapotranspiration from DAIS data: Application to the DAISEX campaigns. Journal of Hydrology, 315: 117-125.

Stuebe, M.M. \& D.M. Johnston, (1990). Runoff volume estimation using GIS techniques. Water Resources Bulletin. 26(4): 611-620.

Thornthwaite, C. W. (1948). An approach toward a rational classification of climate. Geog Rev 38(1): 55-94.

Thornthwaite, C. W., \& Mather, J. R. (1957) Instructions and Tables for computing potential evapotranspiration and the water balance. Publ Climatol 10(3). 